\title{
Kliinilised teenused jutluste asemel ${ }^{1}$
}

\author{
Tuija Hovi
}

Teesid: Institutsionaalse religiooni tähenduse kahanemine on viimastel aastatel olnud väga kiire, kuid samal ajal on tähelepanuväärselt mitmekesistunud religioossed valikud. Lisaks mittekristlikele spirituaalsetele ja religioossetele alternatiividele pakuvad oma teenuseid ka kristlikud ilmikliikumised. Artikkel käsitleb kristlikku eestpalveteenistust Healing Rooms, mis püüab kohanduda Soome tänapäevaste postsekulaarsete oludega ja kaitsta samal ajal oma traditsioonilist evangeeliumi kuulutamise ülesannet.

Märksõnad: eestpalve, Healing Rooms, palvekliinik, religioon, Soome

Tänapäeval seisame silmitsi olukorraga, kus institutsionaalse religiooni tähendus kahaneb. Soomes on peavoolu Evangeelse Luterliku Kiriku liikmeskonna vähenemine olnud viimase mõne aasta kestel ebatavaliselt kiire, kuid samal ajal on tähelepanuväärselt mitmekesistunud religioossete valikute võimalused. Evangeelse Luterliku Kiriku vastu suunatud kriitika on kahesugune: ühelt poolt on kirikut peetud liiga liberaalseks, sest see aktsepteerib kõike, suutmata tõmmata piire, ega väljenda selgelt oma moraalipõhimõtteid. Teiselt poolt on kirikut kritiseeritud, et see on liiga hierarhiline, konservatiivne ja normatiivne ega pööra piisavalt tähelepanu erinevustele ja tänapäeva ühiskonna vajadustele. Lisaks mitte-kristlikele spirituaalsetele ja religioossetele alternatiividele pakub oma teenuseid ka lugematu hulk kristlikke ilmikliikumisi, toiminguid ja praktikaid nii mitte-sektantlikes ringkondades kui ka neis, mis on seotud tihedamalt luterliku kirikuga.

Soome religiooniväljal toimuvad muutused leiavad aset peamiselt kristlikus kultuuriruumis. Lisaks nähtavatele organisatoorsetele muutustele Soome religioossel maastikul leiab aset ka teatud kaasaegsete religioossete arusaamade killustumine. Sellised muutusi on täheldatud kõikjal läänemaailmas - konventsionaalsed mõisted 'uskumine' ja 'kuulumine' ei tundu sobivat enam 
õigupoolest millegi kirjeldamiseks. Üldpildi muudavad veelgi nüansirikkamaks 'praktiseerimine' ja ‘osalemine' religioossuse dünaamiliste aspektidena. Näitena religioossest kaasatusest sellises raamistikus käsitlen järgnevalt kristlikku eestpalveteenistust, mille kohta kasutatakse ingliskeelset nimetust Healing Rooms. See on religioosne praktika, mis püüab kohanduda kaasaegse postsekulaarse Soome oludesse, kaitstes samal ajal oma traditsioonilist evangeeliumi kuulutamise ülesannet. Käesolev artikkel põhineb etnograafilisel materjalil ja küsimustikul, mis jagati neid teenuseid kasutavatele inimestele.

\section{Uskumine, kuulumine, praktiseerimine ja osalemine}

Religioossuse defineerimine kui uskumisena kuuluvuseta (Davie 1994), või olen spirituaalne, kuid mitte religioosne (Fuller 2001) viitavad suhtumisele, mis on laialt levinud tänapäeva soomlaste seas, kes on eemaldunud ametlikust usulisest kuuluvusest ja institutsionaliseeritud organisatsioonidest. Hoolimata sotsiaalse dimensiooni puudumisest võivad need inimesed tunnistada, et nende elus on olemas spirituaalne aspekt, mis tähendab, et nad kogevad midagi, mis on neist endast enamat ning millel on nende silmis tähendus ja millega seostub sotsiaalne sidusus, kuid nad ei taha siduda end mõne kindla religioosse traditsiooni või jumalusega (nt Bandura 2003: 170). On tüüpiline, et need inimesed ei näe oma spirituaalsel/vaimsel elul mingit seost ühegi organiseeritud religioosse rühmaga (McGuire 2008: 98). Usklike kogukonna liikmeks olemine ei ole nende spirituaalses/vaimses elus oluline teema; Grace Davie on võtnud sellise olukorra kokku sõnades: "püha peab vastu, kuid mitte oma traditsioonilistes vormides" (Davie 1994: 228). Siiski, nagu on osutanud religioonipsühholoog Ulrike Popp-Baier, on sageli osundatud väide 'ma olen spirituaalne, aga mitte religioosne' mitmetähenduslik, sõltudes sellest, mida mõistetakse sõnaga 'spirituaalne', mis ei ole sugugi ühetähenduslik mõiste. Mõnikord osutab see sõna olukorrale, kus ollakse hüljanud konservatiivne ja institutsionaalne kristlus ning see asendatakse sama religiooni liberaalsemate tõlgendustega ning isiklikuma panustamisega. Seda sõna kasutatakse aga sageli ka märkimaks näiteks, et ei olda kristlane ning, et inimesel on isiklik suhe Jumala ja jumalikuga, ollakse teadlik oma sisemisest minast või ollakse kontaktis universumiga (Popp-Baier 2010: 44).

Sellal kui uskumist kuuluvuseta on nähtud Lääne sekulariseerunud ühiskondade trendina alates Grace Davie (1994) tähelepanekust sõjajärgse Suurbritannia kohta, on üllatav et muidu mittereligioossed ja mittespirituaalsed inimesed võivad väita religioosset kuuluvust, väljendamaks oma kokkukuuluvust kirikuliikmetena. Võttes arvesse suhteliselt kõrget kirikuliikmete prot- 
senti Soomes, ${ }^{2}$ seda hoolimata hiljutistest 'mass-lahkumistest' näib kuulumine uskumiseta olevat paljudel puhkudel soomlaste religioosse orientatsiooni asjakohane iseloomustus. Sellal kui osa inimestest leiab koguduseliikmeks oleku kaudu vaimset/spirituaalset arengut ja toetust, võib see teistele olla soovitava identiteedi väljendus (McGuire 2008: 98; vrd Day 2010: 19). Seda võib ka näha uskumisena kuulumisse, nagu seda on noorte seas Suurbritannias kirjeldanud Abby Day, rõhutades religioosse kuuluvuse sotsiaalset aspekti olulisemana kui religioossete uskumuste tõeseks ja tähenduslikuks pidamist. Day toob ka ilmekaid näiteid 'uskmatutest kristlastest' (Day 2009).

Tänapäeva religioossus on muutustes, mis rõhutavad ja kombineerivad selliseid protsesse nagu individualisatsioon, demokratiseerimine, muutlikkus, hübridism, relokatsioon ja piiride purustamine. Siiski ei ole traditsionaalne religioon kaotanud oma mõju ega olulisust, nagu on osutanud postsekulaarsusega tegelevad teadlased (nt Habermas 2006, Taylor 2007). Vastupidi, uute religioossete ja spirituaalsete tegevuste ja praktikate levik, killustumise protsessid ja globaalsete võrgustike esilekerkimine avardavad valikuvõimalusi spirituaalsete ja religioossete teenuste vallas. Ka range pühendumine ja äärmuslikud suhtumised leiavad avalikke väljendusvorme, kuigi need ei ole enamuse silmis paeluvad. Sellele viitavad fundamentalistliku kristluse, nagu näiteks evangeelsete ja karismaatiliste nelipühilike liikumiste tõus, mida on nähtud näidetena kristliku spiritualiteedi otsingutest tänapäeva Lääne kultuurides (nt Woodhead 2002; Roof et al. 1995).

Soomes on alates 1990. aastate algusest erinevad sõltumatud uuskarismaatilised kogudused pakkunud fundamentalistlikku kristlikku valikut neile, kes vajavad kogemuslikumat religioossust. Siiski on nende rühmade tegelik pühendunud liikmeskond suhteliselt väike. Kui lõdvalt organiseeritud palvekogukonnad ja -võrgustikud, evangelisatsiooniüritused ja vaimuliku abi teenistused on kogunud rohkem poolehoidjaid ja kasutajad, siis koguduste uute pühendunud liikmete hulk ei ole tähelepanuväärselt kasvanud. Need uued trendid on leidnud toetuspinna nii enamuskirikust väljaspool kui ka selle sees, üldjuhul koguduste ilmikliikmete tegevuses. Sellisteks headeks näideteks, kus side peavoolu evangeelse luterliku kirikuga on säilinud, on kodugrupid ja palverühmad, alternatiivsed jumalateenistused, kus ilmikliikmetel on aktiivne roll, nagu näiteks Toomamissa; ${ }^{3}$ karismaatilised sündmused nagu näiteks Sõna ja Palve, aga samuti praktikad, mille keskmeks on usutervendus, elutreening (life coaching) ja abielunõustamine. Lõppkokkuvõttes võib öelda, et Soome usuelu muutused leiavad aset valdavalt selle kristlikus ruumis või on sellega kaudselt seotud.

Hiljutine uustulnuk Soome usuelus on kristlik palvekliiniku praktika, mille kohta kasutatakse ingliskeelset mõistet Healing Rooms (paranemise toad) 
ning mis on 2006. aastal alanud intensiivse kampaania tulemusel leidnud endale kindla kandepinna. See on ka näide usulise (antud juhul kristliku) praktika ümberpaiknemisest väljaspool koguduslikke funktsioone selliselt, et see ei ole seotud ühegi kindla kristliku liikumisega. Samaaegselt esindab see karismaatilist kristlust oma arusaamadega Püha Vaimu üleloomulikest andidest, karismast, millest üks on tervendamine. Healing Rooms palvekliinikud tegutsevad tervise ja heaolu parandamiseks mille tulemusel eeldatakse kristliku usu suurenemist. Eestpalveteenistuse kaudne põhiülesanne on loomulikult uute järgijate võitmine kristlusele.

Hiljuti on Healing Rooms alustanud tegevust ka Rootsis ja Eestis, kuhu see on jõudnud liikumise Soome harukontori kaudu. Rootsis avati esimene palvekliinik 2012. aasta lõpul Stockholmis ning teine kliinik 2013. aasta kevadel Växjös. Kavatsuste kohaselt avatakse kolmas Rootsi palvekliinik peagi Västeråsis (Healing Rooms 1/2013: 5) Eestis on Healing Rooms tegutsenud Tallinnas ja Tartus samuti alates 2012. aastast (Healing Rooms 1/2012: 3). ${ }^{4}$

\section{Healing Rooms - ajalugu}

Ma tutvustan Healing Rooms nähtust teatud karismaatilise kristluse vastusena postsekulaarsele (ilmalikkusele järgnevale) olukorrale, kus formaalseid institutsionaalseid raame on nähtud piiravate teguritena indiviidi sisemisele arengule ja heaolule, mida mõistetakse olevat spirituaalsed väljakutsed. Healing Rooms on rahvusvaheline eestpalveteenistuse liikumine, mis tegutseb kohalikul tasandil, peamiselt linnakeskkonnas, kliinilise vastuvõtuna. Healing Roomsi idee ulatub tagasi möödunud sajandi esimestesse kümnenditesse. Selle rajaja oli 1930. aastate algul Ameerika Ühendriikide nelipühi pastor John Lake Washingtoni osariigist Spokanest. 1930. aastatel jäi see ühe mehe usuäratuslikuks liikumiseks ning hääbus pärast John Lake'i surma 1935. aastal. Healing Roomsi taaselustas 1990. aastatel üks teine nelipühi pastor, Cal Pierce, kes avastas doktor Lake'i unustatud arusaamad ning hakkas levitama sõnumit denominatsioonide ülesest globaalsest võrgustikust, asutades kohalikke palvekliinikuid, nagu seda eestpalve teenistust nimetama hakati.

Healing Roomsi naasmisele 1990. aastatel järgnes uuskarismaatilise liikumise tõus, mida tuntakse ka 'tervise ja rikkuse evangeeliumina', sest see rõhutab tervenemist ning vaimset ja materiaalset heaolu kui tõeliste usklike privileegi. Nii on see temaatiliselt teatud jätk või lisa nelipühilikule karismaatilisele ärkamisele, isegi kui seda otseselt sellega ei seostata. Healing Roomsi võib nimetada karismaatiliste liikumiste võrgustikuks, mis ei seo end ühegi kindla kristliku kiriku või liikumisega, vaid püüab pigem teha koostööd nen- 
de kõikidega. Healing Rooms on ka lugu edukast globaalsest võrgustikust, mis on laienenud väga kiiresti igale kontinendile ning kasutanud laienemisel juba olemasolevaid toimivaid kohalikke religioosseid taristuid. Selle liikumise peakorter asub Spokanes, Ameerika Ühendriikide Washingtoni osariigis. 2001. aastal asutati International Association of the Healing Rooms (Healing Rooms Ministries rahvusvahelise peakorteri veebileht).

Soomes tutvustas Healing Rooms palvekliinikut abielupaar, kes oli oma puhkusereisil Californiasse tutvunud sellise kliiniku tegevusega kohalikus Vineyardi koguduses. ${ }^{5}$ 2006. aastal rajasid nad esimese palvekliiniku Soomes ning asusid korraldama liikumise organisatoorset külge, töötades välja treeningkursuse neile, kes soovisid saada kohalike kliinikute palvetiimi liikmeteks. 2013. aasta kevadeks oli Soomes asutatud 29 kohalikku kliinikut. Organisatsioon tegutseb Soomes erinevates organisatoorsetes kontekstides, nii nelipühilaste, vabakiriklike koguduste kui ka peavoolu evangeelses luterlikus kirikus. Sellisena ületab see erinevate kirikute ja denominatsioonide vahelisi piire. Palvekliinikud võivad tegutseda ka täiesti ilmalikus keskkonnas, nagu näiteks kaubanduskeskustes või mujal avalikus ruumis. Soome juhtliikmed märkisid, et kohalike palvekliinikute korraldamise üks põhimõte on, et palvekliinik peaks olema olemas igaühele, seda nii vaimselt kui ka füüsiliselt (IF mgt 2011/105). Selleks, et palvekliinikud oleksid kättesaadavad, asuvad nad alati linnakeskustes, kus on toimiv ühistranspordisüsteem. Ruumid, kus palvekliinikud regulaarselt tegutsevad, on valitud selliselt, et ligipääs ei oleks kellelegi takistuseks. See on põhjus, miks palvekliinikuid ei korraldata kirikutes, mida võib pidada liiga ametlikuks või kaugeks kohaks isiklike ja eraeluliste küsimuste puhul.

\section{Healing Roomsi praktika keskkond ja tegurid}

Palvekliiniku praktika kirjeldus põhineb etnograafilisel välitööl, mille viisin läbi kevadel 2011. Materjali selleks artikliks kogusin selliste meetoditega nagu temaatiline intervjuu ja osalusvaatlus, samuti kasutasin küsimustikku. Ma intervjueerisin selle liikumise Soome juhtpaari liikumise keskuses ning 28 palvetiimide liiget, kes esindavad kokku viit kliinikut, sealhulgas Espoos asuvat peakorterit. Lühikene küsimustik anti igale palvekliiniku külastajale kogu riigis.

Palvekliinikutes on kaks omavahel seotud rühma: sisering hoolikalt valitud ja treenitud palvetiimi liikmetest ning nende kliendid ehk inimesed, kes külastavad palvekliinikut eesmärgiga, et nende eest palvetataks. ${ }^{6}$ Kohalikke Healing Rooms kliinikuid korraldatakse kord nädalas või üle nädala. Enne tegeliku 
vastuvõtu avamist klientidele valmistavad palvetiimi liikmed end tunni aja jooksul ülistades ja palvetades ette. See aitab palvetiimi liikmetel end kokku võtta ja keskenduda oma ülesandele ning olla klientidele lähedal. Palvetiimi liikmed, keda ma intervjueerisin, pidasid seda ettevalmistuse osa vajalikuks, et olla valmis olema vahendaja, kanal, nagu nad end ise nimetavad, Jumala ja kliendi vahel. Pärast spirituaalseid ettevalmistusi moodustavad tiimi liikmed kolmeliikmelised (soovitavalt segasoolised) teenimistiimid.

Tegelik klientide vastuvõtt kestab kaks tundi. Kliendid ootavad oma eestpalve korda ooteruumis, kus neist igaüks on vastuvõtjalt saanud täitmiseks ankeedi. Pärast seda, kui kliendid on pannud kirja oma palvesoovid, kutsutakse nad ükshaaval palvetuppa - nagu haigla operatsioonisaali - kus ettevalmistuse saanud kolmeliikmelised palvetiimid palvetavad kliendi eest privaatselt vastavalt tema soovile. Ühe vastuvõtu ajal käib kliinikus tavaliselt keskmiselt 10 külastajat ning nende hüvanguks töötab kaks kuni neli tiimi.

Vestlus kliendiga peaks olema minimaalne. Eriti rõhutatakse, et Healing Roomsi teenistus ei sisalda eraldi teraapia stiilis vestlust. Sel põhjusel seisavad nii palvetiimi liikmed kui ka klient kogu palve vältel, mis kestab 10-20 minutit. Kui inimesed selle protsessi ajal istuksid, võiks olukorda kergesti tõlgendada raviseansina, millena aga Healing Rooms ei ole ette nähtud. Pärast palvetamist võivad kliendid jääda ooteruumi nii kauaks kui nad soovivad, seal on võimalus maitsta suupisteid ja jooki ning saab lugeda buklette, kuid muud programmi neile ei pakuta; ei anta õpetust ega laulda laule. Palvetamine erinevatele probleemidele lahenduse saamiseks on ainus teenus, mida pakutakse, ning muude vajaduste puhul soovitatakse klientidel pöörduda oma kodukoguduse, arsti või teiste elukutseliste aitajate poole.

Standardne ettevalmistus on Healing Roomsi autoriseeritud tiimiliikmeks saamise vältimatu eeltingimus. Kaks päeva kestev ettevalmistuskursus sisaldab palvedemonstratsioone ning karisma õpetust ning samuti orientatsiooni rangete ja selgete reeglite järgimiseks kliendiga kohtumisel. Klienti tuleb kohelda austavalt ning rahulikul ja diskreetsel moel ning näiteks kliendile mõistmatus keeles palvetamine ei ole lubatud, sest see võib olla mõnele kliendile ebamugav. 'Käte peale panek' on tüüpiline kristlik rituaalielement, eriti õnnistamise või tervendamise juures. Siiski ei puudutata klienti Healing Rooms palveteenistusel ilma tema eelneva nõusolekuta. Lähedusega seotud kultuuriliste normidega arvestamist peetakse privaatsuse austamisel oluliseks. See on tähelepanuväärne detail, sest Põhjamaades ei ole tavapäraselt aktsepteeritud puudutamine või kallistamine nende inimeste puhul, keda isiklikult ei tunta. Karismaatilistel koosolekutel on tüüpiline olukord aga sageli vastupidine ning sageli tekitab see uustulnukates segadust. Selles osas esindab Healing Rooms vähem pealetükkivat lähenemist, mis on omasem enamikule soomlastest, sh peavoolukiriku liikmetele. ${ }^{7}$ 
Palvetiimi liikmed teenivad kohalikes Healing Roomsi kliinikutes vabatahtlike töötegijatena. Neid valitakse ja valmistatakse ette kohtumiseks erineva taustaga inimestega. Kõige olulisem tingimus tiimiliikmele on, et ta on usklik, kes kuulub kristlikkusse kirikusse või kogudusse; see, millisesse nimelt, ei ole oluline. Standardiseeritud koolitus on vältimatu eeltingimus Healing Room$s$ i palvetiimi liikmeks saamisel. Need ettevalmistuskursused toovad kokku erineva kristliku taustaga usklikke, kelle seas on ka neid, kellel puudub soov palvetiimiga ühineda. Soomes on kursustel osalejad valdavalt pärit luterlikust kirikust, nelipühilusest ja vabakirikutest.

Seevastu klientidelt ei nõuta oma usulise kuuluvuse teatamist ega millegi tunnistamist, kui nad seda ei soovi. Õhustik peab olema kerge, turvaline ja klientidele mugav ning mitte kohut mõistev. Siiski, kui klient ei ole usklik, palvetatakse nende pöördumise eest n-ö ridade vahel. Lõppkokkuvõttes on Healing Roomsi palveteenistuse põhieesmärk uute inimeste võitmine kristlaste sekka. Kõikidel minu intervjueeritutel oli väga tugev motivatsioon evangeliseerimiseks. Peateema, mida Healing Rooms propageerib, on holistlik heaolu, mis väidatakse eeldavat kristlikku eluviisi, kuid usu tunnistamist ei suruta avalikult peale. Aktiivne pööramine ei ole lubatud ning tiimiliikmetel soovitatakse tungivalt olla sensitiivsed klientide kogemuste suhtes ebameeldivates olukordades ning vastuvõtlikud klientide tagasiside suhtes.

\section{Healing Rooms palveteenistuse tarbijad}

Klientidele suunatud küsimustik (HRQ 2011) jagati laiali kõikides Soomes tegutsevates palvekliinikutes 2011. aasta märtsi lõpust kuni mai alguseni. Palusin, et küsimustikku pakutaks klientidele kliiniku vastuvõtus. Vastuste hulk erinevatest kliinikutest oli erinev, sest ka klientide arv erines kliinikuti. Intervjueeritavate vastuste kohaselt oli keskmine klientide hulk ühe õhtu jooksul 5-10. Kõige rohkem vastuseid laekus Soome Healing Rooms keskusest Espoos (22 vastust), kuid kolmest kliinikust ei tulnud ühtki vastust. Kokku laekus vastuseid 124. Sellise küsimustiku jagamise puhul tuleb arvestada, et see ei hõlmanud neid kliente, kes külastasid ühel või teisel põhjusel kliinikut üksnes ühe korra. Kuigi nende kogemused võib olla väärtuslik materjal, ei olnud võimalik jõuda nendeni kliinikute vahendusel.

Küsimustele vastanute seas oli nii juhukülastajaid kui ka regulaarseid külastajaid, ehk siis nii neid, kes külastasid kliinikut esimesi kordi kui ka neid, kes olid kliiniku tegevusega tuttavamad. Respondentidest 30,64\% olid esmaskülastajad, mis tähendab, et enamik külastajatest tarbib teenust rohkem või vähem regulaarselt. Suur enamus vastanutest - 74,19\% - kuulus ka Soome Evangeelsesse Luterlikku Kirikusse, enamuskirikusse, kuhu kuulub enamik 
elanikkonnast. Seitse vastanut ei kuulunud ühtegi religioossesse kogukonda ning umbes sama palju oli uuskarismaatiliste kogukondade liikmeid. Ülejäänud oli vabakirikute liikmed $(9,7 \%)$ ja nelipühilased $(12,9 \%)$.

Nominaalne liikmeksolek ei ütle siiski palju inimese religioossuse kohta. Et saada rohkem teavet inimese isikliku religioossuse kohta, küsisin ka inimeste usulistest talitustest osavõtu kohta ja huvist nende vastu ehk siis nende usulisest praktikast ja osalemisest. Ei olnud suur üllatus, et $78 \%$ vastanutest osales regulaarselt rohkemal või vähemal määral karismaatilistel jumalateenistustel või kogunemistel. 12,9\% vastanutest ütles, et nad ei osale ühelgi teisel religioossel või spirituaalsel sündmusel peale juhuslike või regulaarsete käikude kohalikku palvekliinikusse. Üldiselt oli huvi (mittekristlike) spirituaalsete teenistuste vastu üpris väike. Küsimustiku vastuste kohaselt kasutavad Healing Roomsi teenuseid üldjuhul kristlased, kes tõmbavad selge piiri kristlike arusaamade ja New Age'i vahele. Sellest järeldub, et Healing Rooms on ligitõmbav neile, kes on juba rohkemal või vähemal määral tuttavad nelipühiliku karismaatilist tüüpi kristlusega. Veelgi enam, nende vastused peegeldavad omaksvõetud kristlikke arusaamu, nagu viited Jeesusele ja Jumala väele. Siiski märkis $20,26 \%$ vastanutest, et nad on proovinud või kasutanud teisi spirituaalseid teenuseid; enamik neist mainis reikit, spirituaalset tervendajat, ingliteraapiat, energiatervendamist ja Roseni teraapiat. ${ }^{8}$

Enamik respondente (71\%) olid naised. See on samuti tüüpiline, sest Soomes on naised aktiivsemad usulistel talitustel osalejad sõltumata sellest, kuidas osalemist mõõdetakse (Kääriäinen et al. 2005). Siiski osutasid intervjuud, et meeste osatähtsus klientide hulgas oli 2011. aasta kevadel kasvamas. Küsimustikule vastajatest $25 \%$ olid mehed. Osa vastanutest ei määratlenud oma sugu. Vanuseliselt võis täheldada, et kliinilise eestpalve teenistused paelusid eelkõige keskealisi. Suurim vanuserühm vastanute seas oli $36-45$ aastased $(31,45 \%)$, suuruselt teise rühma moodustasid 46-55aastased (24,19\%), kellele järgnesid 56-65aastased $(20,16 \%)$. Nooremaid kui 30 aastat ja üle 60aastaseid oli vähe, ning väga noored ja väga vanad puudusid täiesti. Nii võib öelda, et kliendid esindasid aktiivselt tööelus osalevaid vanuserühmi.

Haridust puudutavale küsimusele vastas $44,35 \%$ vastanutest, et neil on kutseharidus, veidi vähem $(36,30 \%)$ oli kõrgharidusega inimesi. Ülejäänud olid kas tudengid või põhiharidusega. Vanuserühmadega seoses tuleb märkida, et üllatuslikult tähelepanuväärne oli pensionile jäänute hulk (29\%). See tulemus võib osutada näiteks asjaolule, et palvekliinikute klientide seas on arvukalt töövõimetuspensionil olijaid. Suurima elukutsekategooria vastanute seas moodustasid vaimulikud (31,44\%), suuruselt teine rühm olid töölised (17\%) ning ettevõtjad moodustasid vastanutest 7,25\%. 2011. aasta kevadel oli Soomes töötuse määr $8 \%$, mis oli nähtav ka küsimustikule vastanute seas $-8,87 \%$ vastanutest olid töötud. 


\section{Usu praktiline perspektiiv}

Nagu artikli pealkiri viitab, ei ole religiooni institutsionaliseerutud vormid tingimata piisavad isegi nende institutsioonide liikmete silmis, sellal kui teistele on need ülemäärased. Palveteenistus, mis on täiesti väljaspool tavapärasest jumalateenistusest ja koguduslikust elust, näib köitvat neid, kes otsivad praktilist ja fokusseeritud vaimset abi kas oma igapäevaeluks või mõne konkreetse akuutse mure puhul. Lisaks sellele, et sellised teenistused on kergelt kättesaadavad, tähendab Healing Roomsi madal künnis, et midagi ei peeta liialt triviaalseks, et selle eest palvetada ning iga soovi võetakse ühtmoodi tõsiselt, nagu üks palvetiimi meesliige innustunult seletas:

...kui klient tuleb, ja, kui ta kassi kaelarihm on kadunud ja ta tahab, et palvetataks, et ta selle üles leiaks, siis me palvetame selle eest. See ei ole veidram sellest, kui keegi palub, et palvetataks tema halvaloomulise vähkkasvaja pärast. [---] Kui Jumal kontakteerub inimesega, lastes leida tal kassi jalutusrihma, siis miks mitte? (IF mgt 2011/075.)

Tüüpilised palvesoovid on sageli seotud füüsilise haigusega, aga ka sotsiaalsete suhete ja psühholoogiliste probleemidega. Sageli palutakse palvetada ka rahaliste probleemide ja töötuse pärast. Healing Roomsi sügavam eesmärk on evangeliseerimine, mida tehakse aga eksklusiivselt palvetamise kaudu ning palvetamine järgib klientide soove. Kliendid kirjutavad üles oma eestpalvesoovid, mis edastatakse palvetiimile. Põhimõtteliselt jagunevad palvesoovid kahte kategooriasse. Üks kategooria on soovid, mis puudutavad haigust või ebamugavust ning teine kategooria on sotsiaalsete sidemete ning emotsionaalsete ja mentaalsete probleemide eest palvetamine. Tüüpilised füüsilised probleemid, mille eest palvetatakse, on pikaajaline või püsiv valu, kroonilised haigused või tervisehädad, mis ei ole tingimata meditsiiniliselt diagnoositud, kuid mida kogetakse valulise ja piiravana.

Palvesoovide teine kategooria hõlmab igapäevaelu ning sisaldab eneses nii kodu, tööd kui sotsiaalseid suhteid puudutavaid eestpalve soove; ka palvetamine sugulaste eest, samuti ängistuse, depressiooni ja unetuse eest. Tiimiliikmete väitel on aja jooksul rõhk füüsiliste haiguste ja praktiliste asjade eest palvetamise soovidelt liikunud rohkem psühholoogilistele ja otseselt spirituaalsetele valdkondadele. Raskused sotsiaalsetes suhetes ning kriisid abielus ja perekonnas, üksindus ja tööelus läbipõlemine, samuti töötus on teemad, mis on palvesoovides sageli märgitud. Emotsionaalselt ja spirituaalselt 'tervikuks saamine' on viie tegevusaasta jooksul muutunud tervendusõhtutel olulisemaks, seevastu tegevuse alguses oli fookus füüsilisel tervenemisel. Selle muutuse osalise põhjusena võib näha asjaolu, et enamik klientuurist on püsikliendid; klientidel võib palvepraktikaga lähemalt tutvudes nihkuda rõhuasetus aja jooksul igapäevaelu otsestelt vajadustelt abstraktsematele teemadele. 
$79,2 \%$ respondentidest oli saanud meditsiinilist ravi seoses nende haigustega, mille eest palvetati. 33,6\% vastanutest ütles, et palvesoovis esitatud probleemide puhul oli sekkutud ka psühhoterapeutiliste vahenditega. Nii võib öelda, et Healing Roomsi palveteenuseid kasutatakse saadava vaimse toetuse pärast ning mitte kõikvõimsa ravina. Palvetiimi liikmete kinnitusel ei soovitata klientidel loobuda meditsiinilisest ravist, kui nad seda saavad ega panda lootust imetervenemisele. Vastupidi: neid julgustatakse olema hoolikad ravimite kasutamisel ning otsima professionaalset abi haiguste puhul.

Isiklikku hinnangut palve mõjule püüti leida küsimustikus oleva küsimusega: "Kas sa oled kogenud, et palve sind aitab?" Küsimustikus oli ka ruumi vastuse täpsustamiseks. Selle küsimuse vastusena selgus, et 94,4\% vastanutest tundis, et eestpalvel oli nende elule positiivne mõju ning see oli aidanud neid ühel või teisel moel. Suhteliselt vähesed respondendid $(64,8 \%)$ tõid näiteid või seletasid lahti palve positiivse mõju. Mõned vastustest olid üksnes loosunglikud kokkuvõtted palve mõjust:

Jumal vastas mu palvetele (HRQ 2011/120).

See tervendab (HRQ 2011/038).

See paneb mind end paremini tundma (HRQ 2011/114).

SEE TÖÖTAB!! (HRQ 2011/085).

Mõni vastanu kirjeldas oma kogemusi täpsemalt. Füüsilist tervenemist ja imesid on peetud usutervendamise kõige tähtsamateks väljunditeks ning veelgi enam on see retoorilisel tasandil tähtis nelipühilikus karismaatilises jutluses. Võttes arvesse, kui oluline on usutervendamise kuvandis füüsiline ja imeline tervenemine, oli vastanute seas üllatavalt vähe neid, kes väitsid end olevat kogenud midagi väga konkreetset ja vahetut. Täpsemalt: üksnes $16 \%$ respondentidest olid tervenenud haigusest, vigastusest või füüsilisest valust. See tulemus osutab, et enamik Healing Roomsi klientidest otsis midagi muud kui lihtsalt füüsilist ravi.

Veidi rohkem kui pool vastanutest, kes andsid mingisuguse kirjelduse, kuidas palve oli neid aidanud (53/101) seletas seda oma elukorra kirjelduse või meeleseisundi kaudu. Palveteenistuse järgseid tundeid ja selle mõju kirjeldati näiteks nõnda:

Palve abil saab olukord selgemaks ja probleem saab õige perspektiivi (HRQ 2011/081).

See rahustab mind, ma olen saanud jagada oma koormat ja tundnud, et keegi, kes minu eest palvetab, hoolib minust (HRQ2011/079). 
Ma olen paremas tujus, mõnikord mitu päeva järjest (HRQ2011021).

Ma saan julgust, mõistan probleemi paremini, saan abi emotsionaalsetele muredele, näiteks rahu (HRQ 2011/080).

Palveteenistuse terapeutiline funktsioon on ilmne. Nagu teine tsitaat otseselt osutab, mõistetakse interaktsiooni kliendi ja palvetiimi liikme vahel hoolitsusena, osutades, et ollakse saadud sotsiaalset tuge, mida ei ole olnud piisavalt. Olemasolevaid raskusi võidakse näha uues valguses ning nõnda võib probleemidele lahenduse leidmine olla saavutatavam. Vastustes kasutatud sõnavara osutab, et viited kristlikule õpetusele olid suhteliselt sagedased. Siiski ainult üks respondent viitas otseselt arusaamale karismast kui kanalist:

...Ma olen saanud Jumalalt sõnumeid ja vastuseid palvetiimi liikme nägemuste kaudu (HRQ 2011/031).

Palvetiimi liikmed rääkisid intervjuudes omalt poolt palju karisma tähendusest nende töös. Kuid kuna nad tõmbasid selge joone oma siseringi kohtumiste ja klientidega tehtava töö vahele, siis rõhutasid nad põhimõtet, mille kohaselt oma karismat nagu näiteks glossolaaliat või prohveteerimist ei kasutata töös klientidega. Seega on antud juhul kliendi isiklikud teadmised karismaatilisest kristlikust traditsioonist ilmsed. Sagedamini puudutasid vastused üleinimliku entiteedi kontrollimist ja aitamist, Jumala headust, mõned märkisid ka usu tugevnemist:

See rahustab mind, see aitab mind mõista, et selles maailmas on midagi suuremat kui meie (HRQ 2011/095).

Jumal on vabastanud mind ahelatest, andnud mulle rõomu depressiooni asemel (HRQ 2011/060).

Jeesus saab väga kalliks (HRQ 2011/086).

Siiski märkis 41,6\% (ligi pool vastanutest), et palvest ei olnud neile kasu. Need respondendid, kes olid kogenud pettumust hoolimata nende eest palvetamisest, ei olnud ka nii varmad andma seletusi kui need, kes teatasid, et nad olid saanud positiivse tulemuse. Kui mittetoimivat palvet seletati või kommenteeriti, siis tehti seda peaaegu alati piibellike mõistete abil, viidates enamasti Jumala tahtele (20\%). Üks vastanutest seletas "palvevastuste" puudumist Saatana sekkumisega ning kaks korda mainiti ka uskmatust. Sagedamini nähti põhjusena, et ei ole õige aeg palve teoks saamiseks $(16,8 \%)$. Palve mittetoimimise põhjuseks loeti ka isiklikke vigu (19,2\%), mille alla kuulusid valed soovid, mis Jumalale heameelt ei valmista, ka see, et need soovid ei ole head inimesele endale; samuti kannatamatust, pinges olekut ja rahutust, ${ }^{9}$ kangekaelsust, kal- 
lutatud soove, kiirustamist, ebakindlust ja andestamatust. Põhimõtteliselt olid kõik vastused tõsised; ainult üks respondentidest võttis küsimust mõningase huumoriga ning andes sellest märku naeru emotikoniga:

Jumalal on võib-olla muud teha...:-) (HRQ 2011/090)

13,6\% vastanutest väljendas oma teadmatust palve mittetoimimise põhjustega seoses ning peaaegu pool $(47,2 \%)$ neist ei kommenteerinud kuidagi võimalust, et palve neid ei aita. Ühe vastanu silmis oli küsimus nii irrelevantne, et ta kriipsutas selle läbi.

Küsimustiku vastuste põhjal on ilmne, et enamikul Healing Roomsi klientidel on kristliku usu intensiivsus erinev. Nende väheste vastanute jaoks, kes ei kuulunud ühtegi usulisse kogukonda, näis individuaalselt organiseeritud palveteenistus olevat sobilik spirituaalne tegevus - kohustuseta kuuluda ühtegi usulisse kogukonda.

\section{Diskussioon}

Selle asemel, et arutleda religiooni väheneva rolli üle ühiskonnas, on palju valgustavam uurida, kuidas kohanevad religioossed traditsioonid uute olukordadega; näiteks uute praktikatena, mis võivad mõnikord omavahel isegi võistelda. Samuti on huvipakkuv, kuidas võtavad traditsioonid omaks funktsionaalselt relevantseid elemente ja ideid, et paremini kohaneda. Näib, et Soomes on Healing Roomsi palveteenistus leidnud oma niši kusagil traditsionaalse, kuid paljude jaoks liialt kammitseva kogudusliku osalemise ja pastoraalse hingehoidliku teraapia vahel. See on pakkunud ühiskonnas huvi ka individuaalse spiritualiteedi ja ühiskonna üldise heaolu raames. Holistliku heaolu perspektiiv võib mõjuda paeluvalt ka paljudele, kes ei pea kollektiivset või liturgilist jumalateenistust piisavaks, küllalt huvitavaks või sobivaks nende usulistele vajadustele.

Nii kohandab Healing Rooms kristlikule usule omase evangeliseeriva misjoni tänapäeva Lääne religioossele ja spirituaalsele turuplatsile, kus keskseteks teemadeks on heaolu ja tervenemine. On märkimist väärt ja sümptomaatiline, et kuigi Healing Rooms aktiivselt vastandub ja võitleb New Age'i tüüpi spirituaalsusega ning tervendamisega muudes kontekstides kui kristlikus, tegeleb ta samal ajal üsna aktiivselt selsamal tegevusväljal, püüdes saavutada holistlikku heaolu. Nagu on osutanud Marion Bowman, on üks 20. sajandi (kahtlemata ka 21. sajandi) spirituaalsuse tunnuseid arusaam tervenemisvajadusest. Näib, et paljude inimeste silmis on tänapäeva soterioloogiaks tervenemine. Nii on rõhuasetus liikunud lunastust puudutavatelt küsimustelt tervenemist puudutavatele küsimustele. Selle asemel, et küsida, mida saan ma teha, et saada 
päästetud? ning mida saan ma teha, et päästa maailma?, küsitakse nüüd, mida saan ma teha, et saada tervendatud? või kuidas saan ma tervendada maailma? (Bowman 1999: 1).

Selleks, et propageerida piibellikku tervendamist, mis järgib Jeesuse eeskuju, tutvustab Healing Rooms oma tegevust Soome populaarsematel New Age'i sündmustel - "Vaimu ja teadmise" messil (Hengen ja tiedon messut) ja "Mina olen" messil ("Minä olen” messut). Need on igasügisesed sündmused, kus New Age’i praktiseerijad esitlevad paari päeva jooksul oma teenuseid. Need foorumid on olulised ka Healing Roomsile, sest messid on 'kohad, kus on otsijad'. Seda võetakse võimalusena võita kristlusele uusi järgijaid, kasutades selleks tervenemise spirituaalset temaatikat. Oma suureks missiooniks peab Healing Rooms "tervenemise kontseptsiooni rehabiliteerimist ja selle tagasi toomist algse piibelliku tähenduse juurde pärast seda, kui selle olid varastanud New Age'i mõtlejad", nagu väitis Soome Healing Roomsi tegevust juhtiv paar (IF mgt 2011/105).

Muidugi on tervenemist seostatud sageli religiooniga (Bowman 1999: 4). Eriti nelipühilikus-karimaatilises kristluses on lunastus ja tervenemine käinud käsikäes ning idee holistlikust tervenemisest, mis hõlmab üheaegselt keha, meelt ja vaimu, on õpetuse fookuses. See teema ja selle praktilised väljendusvormid on veelgi enam rõhutatud sellistes uus-karismaatilistes liikumistes nagu Vineyard, Toronto Õnnistus (Toronto Blessing), Usu Sõna jt. Vastustest minu küsimustikule selgus, et Healing Roomsi teenistus pakub huvi eelkõige inimestele, kes on juba rohkemal või vähemal määral tuttavad nelipühilikkarismaatilise kristlusega. Nii toimib värbamisfunktsioon püüdena muuta passiivsed usklikud oma usus aktiivsemaks. Küsimustiku vastuste valguses võib öelda, et osalemist ilma uskumiseta Healing Roomsi puhul ei täheldatud.

\section{Kokkuvõte}

Pärast seitset aastat aktiivset kampaaniat on Healing Rooms leidnud toetuspinna Soome kristlikus kultuuris ning tasahilju on tegevust laiendatud naaberriikidesse. Kliinilise praktika laadne eestpalve teenistus näib loovat toimiva sümbioosi palvetiimi liikmete ja nende klientide vahel. Tiimiliikmetele pakub aktiivne palve, nagu ka ülistamine koherentses ja demokraatlikus usklike kogukonnas, võimaluse isiklikuks spirituaalseks eneseteostuseks toetavas spirituaalses kogukonnas, mis on keskendunud struktureeritud missioonile oma liikmete seas vastandina lihtsalt kirikupingis istumisele. See loob aktiivsema keskkonna nendele usklikele, kes leiavad, et nende roll või subjektiivsus on hierarhilise struktuuriga kodukoguduse liikmena ühel või teisel moel piiratud. Teenides kliiniliste praktiseerijatena (clinical practitioner) saavad ettevalmis- 
tusega palvetiimi liikmed väljendada oma subjektiivsust ning neil on võimalus täita spirituaalselt enampakkuvamat rolli, ehk teisiti öeldes: neil on võimalus oma religiooni elada.

Healing Rooms ei paku klientidele kogukonda, mille liikmeks astuda, palvekliinik pakub eluga pahuksis olevale inimesele tema isiklikele vajadustele vastavat tuge - lihtsalt kättesaadavat diskreetset ja individuaalset hoolt, mis ei võta palju aega, ei maksa midagi ega oota midagi vastutasuks. Kliendile on see praktika, mida saab vajadusel kasutada kohustuseta end millegagi püsivalt siduda. See on lihtsalt koht, kuhu minna siis, kui on vaja hingehoidu või abi probleemide lahendamiseks või parema enesetunde saavutamiseks. Kliendile tähendab see praktiseerimist ja osalemist kuhugi kuulumata.

\section{Tõlkinud Ringo Ringvee}

\section{Kommentaarid}

1 Originaal: Hovi, Tuija: "Clinical Services instead of Sermons?" Ahlbäck, Tore (toim). Post-secular Religious Practices. Scripta Instituti Donneriani Aboensis 24. Åbo: The Donner Institute for Research in Religious and Cultural History, 2012. Tõlkele on lisatud autori täiendused.

2 Soome Evangeelsesse Luterlikku Kirikusse kuulus 2012. aasta lõpul 76,4\% Soome rahvastikust (http://evl.fi/). Kiriku viimase nelja aasta tegevusaruande kohaselt osaleb ligikaudu pool kiriku liikmetest vähemalt kord aastas mingisugusel kiriklikul sündmusel, milleks ei ole tingimata igapühapäevane jumalateenistus, vaid näiteks "Kauneimmat joululaulut" (Kauneimad jõululaulud) - muusikasündmus, mis on muutunud kiriku kõige populaarsemaks ettevõtmiseks (Haastettu kirkko 2012: 92).

3 Toomamissa toimub Helsingis Mikael Agricola kirikus igal pühapäeval kell kuus õhtul. See on luterlik jumalateenistus, mis on mõjutatud kiriku vanast liturgilisest traditsioonist, samuti oikumeenilisest liikumisest. Jumalateenistus on saanud oma nime apostel Toomase järgi, kellel näis olevat usus rohkem küsimusi kui vastuseid. Toomamissa on ülistusjumalateenistus, mille lähtepunktiks on piibellik lugu sellest, kuidas Jeesus pühitsuses õhtusööki variseri majas, kus viibisid prostituut ja külarahvas (Toomamissa veebileht).

4 Vt www.healingrooms.ee (tõlkija märkus).

${ }^{5}$ Vineyardi kogudusest Eestis vt Ringvee 2012 (tõlkija märkus).

${ }^{6}$ Mõiste 'klient' võib kõlada selles kontekstis eksitavalt, sest seda mõistetakse üldiselt toote ja raha vahetamise kontekstis. Kuigi Healing Rooms teenused põhinevad vabatahtlikul tööl ning on tasuta nende kasutajatele, nimetan kliiniku külastajaid klientideks, sest enamik Soome palvetiimi liikmetest nimetab neid vastava soomekeelse sõnaga asiakas. Põhimõtteliselt ei näinud intervjueeritavad palvetiimi liikmed selle mõiste kasutamises probleeme, kuigi sõnal on teises kontekstis kaubandusele viitav tähendus. Aeg-ajalt kasutatakse Healing Rooms klientide kohta ka teisi mõisteid, nagu näiteks kävijät (käijad/külalised) või rukoiltavat (need, kelle eest palvetatakse).

7 Liikumise juhid Soomes seletasid põhjalikult, kui vajalik on Healing Roomsi kontseptsiooni akulturatsioon, et see oleks Soome kultuuri ja ühiskonna kontekstis hõlpsasti 
vastuvõetav (IF mgt 2011/105). Sotsiaalse suhtluse kultuuriliste normidega arvestamist võib näha selle ühe väljendusena.

8 Selliseid alternatiive, nagu TM (transtsendentaalne meditatsioon), homöopaatia, hüpnoos, intuitiivne tervendamine, kiviteraapia, tšakra avamine ja lilleteraapia, märgiti igaüht üksnes ühel korral.

${ }^{9}$ Selliselt vastas inimene, kes oli ka mediteerinud ning oli tuttav intuitiivse tervendamisega.

\section{Kirjandus}

Bandura, Albert 2003. On the psychosocial impact and mechanisms of spiritual modeling. The International Journal for the Psychology of Religion 13, lk 167-173 (doi: 10.1207/ S15327582IJPR1303_02).

Bowman, Marion 1999. Healing in the spiritual marketplace: consumers, courses and credentialism. Social Compass 46 (2), lk 181-189 (doi: 10.1177/003776899046002007).

Davie, Grace 1994. Religion in Britain since 1945: Believing without Belonging. Oxford: Blackwell.

Day, Abby 2009. Believing in belonging: an ethnography of young people's construction of beliefs. Culture and Religion 10, lk 263-278 (doi: 10.1080/14755610903279671).

Day, Abby 2010. Propositions and performativity: relocating belief to the social. Culture and Religion 11, lk 9-30 (doi: 10.1080/14755610903528812).

Fuller, Robert C. 2001. Spiritual but not Religious: Understanding Unchurched America. Oxford: Oxford University Press.

Haastettu kirkko 2012 = Haastettu kirkko. Suomen evankelis-luterilainen kirkko vuosina 2008-2011, Kirkon tutkimuskeskuksen julkaisuja 115. Porvoo: Bookwell Oy (http://sakasti.evl.fi/sakasti.nsf/0/4D9073DDB9C38745C22576F20030A70E/\$FILE/ Haastettu\%20kirkko.pdf - 2.detsember 2013).

Habermas, Jürgen 2006. Religion in the public sphere. European Journal of Philosophy 14 (1), lk 1-25 (doi: 10.1111/j.1468-0378.2006.00241.x).

Kääriäinen, Kimmo \& Niemelä, Kati \& Ketola, Kimmo 2005. Religion in Finland: Decline, Change and Transformation of Finnish religiosity. Publications 54. Tampere: The Church Research Institute.

McGuire, Meredith B. 2008. Lived Religion: Faith and Practice in Everyday Life. Oxford: Oxford University Press.

Popp-Baier, Ulrike 2010. From religion to spirituality: megatrend in contemporary society or methodological artefact? A contribution to the secularization debate from psychology of religion. Journal of Religion in Europe 3, lk 34-67 (doi: 10.1163/187489209X478337).

Ringvee, Ringo 2012. Karismaatiline kristlus - Vineyard. Altnurme, Lea (toim). Uued usulised ja vaimsed ühendused Eestis. Tartu: Tartu Ülikooli Kirjastus, 2012, lk 47-51.

Roof, Wade Clark \& Carroll, Jackson W. \& Roozen, David A. 1995. Conclusion. The post-war generation: carriers of a new spirituality. Roof, Wade Clarke \& Roozen, Da- 
vid A. (toim). The Post-War Generations and Establishment Religion: Cross-Cultural Perspectives. Boulder: Westview Press, lk 243-256.

Taylor, Charles 2007. A Secular Age. Cambridge: The Belknap Press of Harward University Press.

Woodhead, Linda 2002. Christianity. Woodhead, Linda \& Fletcher, Paul \& Kawanami, Hiroko \& Smith, David (toim). Religions in the Modern World. London: Routledge, lk 153-181 (doi: 10.4324/9780203398494_chapter_7).

\title{
Elektroonilised allikad
}

Soome Evangeelse Luterliku kiriku kodulehekülg http://evl.fi/ (10. november 2013).

Soome Toomamissa kodulehekülg http://www.tuomasmessu.fi/ (10. november 2013).

Healing Rooms koguduste rahvusvahelise peakorteri kodulehekülg http://healingrooms. com/ (10. november 2013).

IF - arhiveeritud intervjuud Turu Ülikoolis.

HRQ 2011 - küsitluste vastused autori valduses.

\section{Summary}

\section{Clinical Services Instead of Sermons}

\author{
Tuija Hovi
}

Keywords: Finland, Healing Rooms, intercessory prayer, prayer clinic, religion

Contemporary religiosity is undergoing a process of transfer that emphasises and combines different processes, such as individualisation, democratisation, fluidity, hybridism, relocation and breaking of boundaries. But traditional religion has not lost its influence and relevance either. An increase in new kinds of religious and spiritual activities and practices, the process of fragmentation and the emergence of global networking are expanding the spectrum of choices in the field of spiritual and religious services. Since the early 1990s, various independent Neo-charismatic congregations in Finland have been offering fundamentalist Christian choices to meet the needs for more experiential religiosity. This article deals with a Christian 'prayer clinic' practice called the Healing Rooms. This clinical practice type of intercessory prayer service seems to provide a functioning symbiosis between the members of prayer teams and their clients. The team members get an opportunity for personal spiritual self-actualisation in a supportive spiritual community and for clients the Healing Rooms offer a tailor-made support for the seamy side of life - discreet and individual care with an easy access that does not take much time, is free of charge, and demands nothing in return. 